\title{
Comparison of the effectivity of handrubbing and handwashing on the number of bacterial colonization on clinical students at the Department of Oral and Maxillofacial Surgery, Faculty of Dentistry, Universitas Sumatera Utara March-May 2018
}

\author{
Ahyar Riza ${ }^{*}$, Abdullah Oes, Hendry Rusdy, \\ Khairun Nisah
}

Abstract

Objective: To compare handrubbing and handwashing effectivity on total bacteria count on clinical students at the Department of Oral and Maxillofacial Surgery, Faculty of Dentistry, Universitas Sumatera Utara March - May 2018.

Material and Methods: This is an experimental study with pre-test pos-ttest group design carried out by purposive sampling technique. In this study, sample were divided into 2 groups and each consist of 20 people which are handrubbing and handwashing groups. Bacterial samples were obtained by placing the right hand in a container that contain $\mathrm{NaCl} 0.9 \%$ solution for 1 minute. Samples were then grown in nutrient agar plate and incubated at $37^{\circ} \mathrm{C}$ for hours. The culture results were calculated using the colony counter tool.

Results: There is a significant difference before and after handrubbing with significance $0.00(\mathrm{P}<0.05)$ and before and after handwashing with significance $0.001(p<0.05)$ in reducing bacterial colonization in hand with. However, there is no significant association between handrubbing and handwashing method in reducing the number of bacterial colonization with a significance number of 0.892 ( $p>0.05$ ).

Conclusion: There is no significant differences between handrubbing and handwashing in reducing the number of bacterial colonization.
Department of Oral and Maxillofacial Surgery, Faculty of Dentistry, Universitas Sumatera Utara, Medan, Indonesia
Keywords: Handrubbing, Handwashing, Bacterial Colonization

Cite This Article: Riza A, Oes A, Rusdy H, Nisah K. 2019. Comparison of the effectivity of handrubbing and handwashing on the number of bacterial colonization on clinical students at the Department of Oral and Maxillofacial Surgery, Faculty of Dentistry, Universitas Sumatera Utara March-May 2018. Journal of Dentomaxillofacial Science 4(2): 105-108. D0l: 10.15562/jdmfs.v4i2.813

\section{Introduction}

Health workers in the field of public and dental health services include dentists, dental nurses and dental care assistants, have long been recognized as a group that is at high risk of disease transmission, considering the work itself involves direct contact with patient's lesion. Transmission that may occur in the dentist's practice room is not only among fellow patient, the dentist may unconsciously receive transmission from infectious disease carriers and transmit it to other patients. ${ }^{1,22}$

Infectious diseases in Indonesia according to Basic Health Research (RISKESDAS) includes tuberculosis and hepatitis. The prevalence of hepatitis in $2013(1.2 \%)$ is twice, higher than in 2007, while the incidence of HIV infection increase every year. The increasing prevalence of people infected with infectious diseases is a condition that should be aware of especially dentist as it is are one of the professions which is prone to cross contamination. Therefore, dentist requires maximum self-protection to protect themselves from cross infection. . $^{3,4}$

An easy method in preventing and controlling infection can simply be done by washing hands using soap or antiseptic liquid (handrub). Antiseptic is chemical compound that can prevent contamination and infection by killing the microorganisms or inhibiting their activities. Prevention and control over infection can be done by maintaining hands hygiene as hands can be considered as transportation media where microorganism can tranverse from host to another, which can occur during medical care. ${ }^{5,6}$

Lack of compliance by medical personnel in the implementation of hand hygiene is a problem faced by hospitals around the world. Lack of facilities such as sinks and access to clean water, soap and tissues at health service places are problems that affect the compliance of handwashing. A possible solution to this is by using alcohol-based handrubs. Based on this fact, the researcher felt the need to compare the effectivity of handrubbing and handwashing on the number of bacterial colonization in the clinical students of the Department of Oral and Maxillofacial Surgery, Faculty of Dentistry, Universitas Sumatera Utara March - May 2018.

\section{Material and Methods}

This is an experimental study with pretest posttest 
Design approach. The non probability sampling with purposive technique is applied to collect samples which are clinical students at Department of Oral and Maxillofacial Surgery in Faculty of Dentistry, Universitas Sumatera Utara. In this study, sample were divided into 2 groups which consist of 20 people which are handrubbing and handwashing groups. Table 1.

The following procedure begins with subject's hand soaked in a container that contain $\mathrm{NaCl} 0.9 \%$ solution for 1 minute. Then WHO hand hygiene method by handrubbing (alcohol $70 \%$ and chlorhexidine gluconate $0.5 \%$ ) and handwashing (chlorhexidine gluconate 4\%) procedure. Hands were gently dried by using paper towel (handwashing) and soaked in a container that contain $\mathrm{NaCl} 0.9 \%$ solution for 1 minute. Samples were then sent to the microbiology laboratory for bacterial cultivation on the plate count agar and incubated for 48 hours. The number of bacterial colonies grown were then counted. Data processing was done

\section{Table 1 Total bacterial count before and after handrubbing}

\begin{tabular}{ccc}
\hline Sample Number & \multicolumn{2}{c}{ Total Bacterial Count $(\mathrm{CFU} / \mathrm{mL})$} \\
\cline { 2 - 3 } & Before Handrubbing & After Handrubbing \\
\hline Rub 1 & 0 & 0 \\
Rub 2 & 259 & 0 \\
Rub 3 & 412 & 0 \\
Rub 4 & 443 & 0 \\
Rub 5 & 79 & 0 \\
Rub 6 & 0 & 0 \\
Rub 7 & 322 & 0 \\
Rub 8 & 251 & 0 \\
Rub 9 & 87 & 0 \\
Rub 10 & 604 & 243 \\
Rub 11 & 940 & 412 \\
Rub 12 & 202 & 0 \\
Rub 13 & 105 & 0 \\
Rub 14 & 83 & 0 \\
Rub 15 & 189 & 0 \\
Rub 16 & 27 & 0 \\
Rub 17 & 380 & 0 \\
Rub 18 & 450 & 0 \\
Rub 19 & 340 & 0 \\
Rub 20 & 400 & 0 \\
\hline
\end{tabular}

with computer analyzed using Wilcoxon and Mann-Whitney test. Table 2.

\section{Results}

The mean result obtained for before handrubbing group was $278.65 \pm 232.462 \mathrm{CFU} / \mathrm{mL}$, for after handrubbing group was $33.2 \pm 104.334 \mathrm{CFU} / \mathrm{mL}$ and before handwashing group was $288.937 \pm 238.77$
$\mathrm{CFU} / \mathrm{mL}$, for after handwashing group was $29 \pm 88.66 \mathrm{CFU} / \mathrm{ml}$. Table 3 .

The mean result obtained for before handrubbing group was $278.65 \pm 232.462 \mathrm{CFU} / \mathrm{mL}$, for after handrubbing group was $33.2 \pm 104.334 \mathrm{CFU} / \mathrm{mL}$ and before handwashing group was $288.937 \pm 238.77$ $\mathrm{CFU} / \mathrm{mL}$, for after handwashing group was $29 \pm 88.66$ $\mathrm{CFU} / \mathrm{ml}$. Table 3.

The statistic test between before and after handrubbing and handwashing groups were analyzed using Wilcoxon test and the $\mathrm{p}$ value $=0.00<0.05$, while between before and after handwashing group the $\mathrm{p}$ value $0.001<0.05$. Table 3 . This results showed that there is a significant differences in the number of bacterial colonies between before and after handrubbing and handwashing.

Further test between handrubbing and handwashing groups were analyzed using Mann-Whitney test. Between handrubbing and handwashing group the $\mathrm{p}$ value $=0.892>0.05$. Table 4 This result showed that there is no significant difference in the number of bacterial colonies between handrubbing and handwashing in routine hand hygiene.

\section{Discussion}

Results showed that there is a significant decrease in the number of bacterial colonization before and after handrubbing and handwashing $(\mathrm{p}<0.05)$. The material in handrubbing used by researchers consists of $70 \%$ alcohol and $0.5 \%$ chlorhexidine gluconate. Decreasing of bacterial colonies in the hands of respondents after handrubbing is caused by the active content contained in them, which is $70 \%$ alcohol.

For the handwashing group, statistical test results showed that handwashing is effective in reducing the amount of bacterial colonization in the hands. The material used for handwashing consisted of $4 \%$ chlorhexidine gluconate. Chlorhexidine is an antiseptic and disinfectant that has bactericidal and bacteriostatic effects on gram (+) and gram (-) bacteria.

There are differences in the number of bacterial colonization before hand hygiene is done either by handrubbing or handwashing. The difference in the number of bacterial colonization was due to several factors, one of the reason was the conducted activity. Activities conducted by clinical students will affect the amount of bacterial colonization. The amount of activity carried will affect the number of bacteria in hand. According to the researchers, clinical students who performed dental treatment had fewer bacteria than clinical students who did not. This is due to the use of gloves on clinical students during treatment and prior treatment handwashing. It can be seen, sample rub 1 and rub 6, 
sample number wash 3, wash 6 and wash 16 had no bacteria before handrubbing or handwashing.

Sample wash 9, wash 11, wash 12 and wash 15 the number of bacteria were uncountable.

Table 2 Total bacterial count before and after handwashing

\begin{tabular}{ccc}
\hline & \multicolumn{2}{c}{ Total Bacterial Count $(\mathrm{CFU} / \mathrm{mL})$} \\
\hline Sample Number & Before Handrubbing & After Handrubbing \\
\cline { 2 - 3 } Wash 1 & 424 & 0 \\
Wash 2 & 475 & 0 \\
Wash 3 & 0 & 0 \\
Wash 4 & 504 & 3 \\
Wash 5 & 432 & 276 \\
Wash 6 & 0 & 0 \\
Wash 7 & 716 & 0 \\
Wash 8 & 6 & 0 \\
Wash 9 & Uncountable & 0 \\
Wash 10 & 30 & 0 \\
Wash 11 & Uncountable & 0 \\
Wash 12 & Uncountable & 1 \\
Wash 13 & 305 & 0 \\
Wash 14 & 104 & 0 \\
Wash 15 & Uncountable & 0 \\
Wash 16 & 0 & 0 \\
Wash 17 & 350 & 0 \\
Wash 18 & 628 & 300 \\
Wash 19 & 324 & 0 \\
Wash 20 & 325 & 0 \\
& &
\end{tabular}

Table 3 The mean of total bacterial count before and after handrubbing and handwashing

\begin{tabular}{llllll}
\hline \multirow{2}{*}{ Group } & \multirow{2}{*}{$\mathrm{N}$} & \multicolumn{2}{c}{ The mean of total bacterial count } & \multirow{2}{*}{\begin{tabular}{c} 
P Value \\
\cline { 3 - 5 }
\end{tabular}} \\
\cline { 3 - 6 } & & Before & $\mathrm{N}$ & After & \\
\hline Handrubbing & 20 & $278.65 \pm 232.462 .334 \mathrm{CFU} / \mathrm{ml}$ & 20 & $33.2 \pm 104.334 \mathrm{CFU} / \mathrm{ml}$ & 0.00 \\
Handwashing & 16 & $288.937 \pm 238.77 \mathrm{CFU} / \mathrm{ml}$ & 20 & $29 \pm 88.66 \mathrm{CFU} / \mathrm{ml}$ & 0.001 \\
\hline
\end{tabular}

Table 4 The mean of total bacterial count on handrubbing and handwashing group

\begin{tabular}{lccc}
\hline Group & N & The Mean of Total Bacterial Count & $\begin{array}{c}\text { P Value } \\
\text { Mann-whitney }\end{array}$ \\
\hline Handrubbing & 20 & $33.2 \pm 104.334 \mathrm{CFU} / \mathrm{ml}$ & 0.892 \\
Handwashing & 20 & $29 \pm 88.6 \mathrm{CFU} / \mathrm{ml}$ & 0.892 \\
\hline
\end{tabular}

This is a condition where too many colonies form in the media and impossible to be calculated. This could occur because of the low dilution factor resulting high concentration of bacteria in the suspension. It could also be caused by uneven distribution hence bacteria grow in a stacked and difficult to be counted.

Sample rub 10, rub 11 after handrubbing and table 4 sample wash 5 , number of bacteria after handwashing were still high. This could be caused by several factors; internal (clinical students) and external (environmental) factors. Internal factors can be caused by treatment duration and activities, handwashing duration, knowledge, experience and handwashing techniques. While external factors include contamination from the environment.

Although statistically there is no significant difference in reducing the number of bacterial colonization between handrubbing and handwashing, the data tend to show the number of bacterial colonization after handwashing is lower.

This is likely to be caused by the antiseptic material used by researchers having different concentrations, in handrubbing concentration of chlorhexidine gluconate is $0.5 \%$ while in handwashing concentration is $4 \%$ chlorhexidine gluconate. The speed of killing microorganisms will increase by increasing concentrations of anti-microbial substances. So this needs to be considered in choosing a method of hand hygiene in a hospital to prevent cross infection.

\section{Conclusion}

Hand hygiene with handrubbing method is equally effective as hand hygiene with handwashing method.

\section{Acknowledgment}

I would like to thank all the Lecturer Department of Oral and Maxillofacial Surgery, Ahyar Riza, Hendry Rusdy and Abdulla Oes for guiding and helping me until the completion of this articles.

\section{Conflict of Interest}

The authors report no conflict of interest.

\section{References}

1. Kementrian Kesehatan RI. Standar pencegahan dan pengendalian infeksi pelayanan kesehatan gigi dan mulut di fasilitas pelayanan kesehatan. Jakarta: Kementrian Kesehatan RI; 2012. p. 9-11.

2. Jabbar U, Leischner J, Kasper D, et al. Effectiveness of alcohol Wased hand rubs for removal of clostridium difficile spores from hands. Chicago J 2010; 31: 571-573.

3. Wibowo T, Parisihni K, Hariyanto D. Proteksi dokter gigi sebagai pemutus rantai infeksi silang. J PDGI 2009;58: 6-9. 
4. Ramadhani WR, Kepel BJ, Parengkuan WG. Tindakan pencegahan dan pengendalian infeksi pada perawatan periodonsia di rumah sakit gigi dan mulut pspdg FK Unsrat. J e-GiGi 2015;3: 409-414.

5. Sax H, Allegranzi B, Chraiti MN, et al. The world health organization hand hygiene observation method. Am J Infect Control 2009;37: 827-834.

6. Gurning D, Riniwasih LK, Lestaryana FD. Uji ketahanan aktivitas handrub sebagai antiseptik tangan di bagian instalasi gawat darurat (IGD), intensive care unit (ICU) dan instalasi kamar operasi (IKO) RS kepresidenan RSPAD Gatot Soebroto. Soc Clin Pharm Indonesia J 2017;2: 10-16.

7. Hanley J, Poh BF, Choudhury S, et al. Alcohol handrubbing and chlorhexidine handwashing are equally effective in removing methicillin-resistant staphylococcus aureus from care health workers' hands: a randomized controlled trial. Am J Infect Control 2015: 1-3.

8. Widmer AF, Conzelmann $M$, Tomic $M$, et al. Introducing Alcohol Wased handrub for hand hygiene: The critical need for training. Chicago J 2007;28: 50-54.
9. Maunah N. Efektifitas aplikasi handrub terhadap perubahan pola mikroorganisme pada tangan petugas di rumah sakit penyakit infeksi prof. dr. Sulianti Saroso. Indonesian J Infec Disease 2013;3: 24-29.

10. Barzah AM, Pradian E, Bisri T. Perbandingan antiseptik chlorhexidine alkohol dengan povidone iodine terhadap penurunan pertumbuhan koloni bakteri pada kateter epidural yang dipasang di kamar operasi rumah sakit dr. Hasan Sadikin Bandung. J Anestesi Perioperatif 2016;4: 21-29.

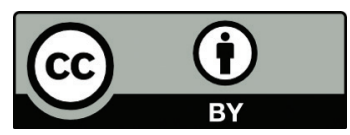

This work is licensed under a Creative Commons Attribution 